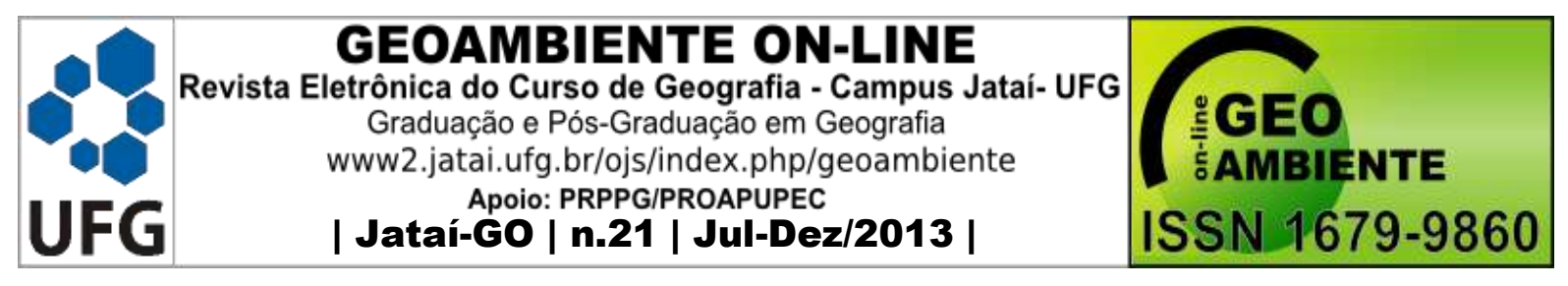

\title{
ANÁLISE DA PROPOSTA DO DESENVOLVIMENTO TERRITORIAL NA REALIDADE BRASILEIRA
}

\section{Evandro César Clemente}

(Universidade Federal de Goiás - Campus Jataí, Professor do curso de Graduação e PósGraduação a nível de Mestrado em Geografia, evandrospfc@ @otmail.com)

\section{RESUMO}

O trabalho aborda as questões suscitadas na realidade brasileira a partir da adoção da abordagem territorial nas políticas públicas de desenvolvimento do campo brasileiro. Foram levantados pontos relevantes para embasar a discussão proposta, como a forma acrítica que ela foi gestada e implementada no Brasil. Além disso, apontamos a forte concentração da propriedade da terra no Brasil como elemento que bloqueia decisivamente muitos dos possíveis efeitos positivos da proposta, além do forte viés neoliberal que a proposta tem se revestido. A crítica também recai no viés oficial dado ao conceito de território, como área em que o conjunto de interesses estão isentos de antagonismos, negando assim a conflitualidade inerente ao processo de desenvolvimento do capital no campo e na cidade. Deste modo, a adoção da proposta do desenvolvimento territorial não tem conseguido mudar de maneira significativa as orientações das políticas públicas no Brasil e menos ainda, tem conseguido trazer significativas alterações na realidade brasileira.

Palavras chave: Desenvolvimento territorial, descentralização administrativa e participação.

\section{ABSTRACT}

\section{ANALYSIS OF PROPOSED DEVELOPMENT LAND IN BRAZILIAN REALITY}

\footnotetext{
Artigo recebido para publicação em 21 de Novembro de 2013

Artigo aprovado para publicação em 29 de Dezembro de 2013
} 


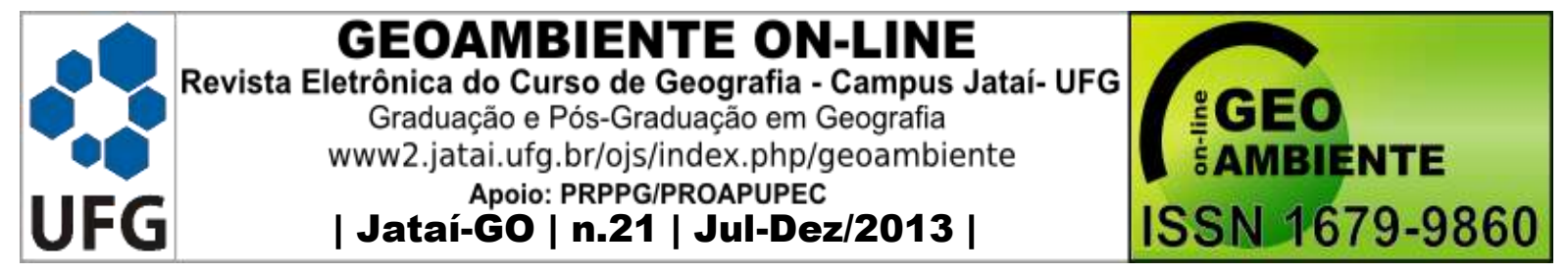

This paper addresses the issues raised in the Brazilian reality with the adoption of a territorial approach in public policy development in rural Brazil . Relevant points were raised to support the proposed discussion, as uncritically she was gestated and implemented in Brazil . Furthermore, we point out the high concentration of land ownership in Brazil as part decisively that blocks many of the possible positive effects of the proposal, in addition to strong neoliberal bias that the proposal has been coated. The critique also falls in the official bias given to the concept of territory as an area in which the set of interests are exempt of antagonism, thus negating the conflict inherent in the process of developing the capital in rural and urban areas. Thus, the adoption of the proposed land development has failed to change significantly the guidelines of public policies in Brazil and even less, has managed to bring significant changes in the Brazilian reality.

Key words: Territorial development, administrative decentralization and participation.

\section{RESUMEN}

\section{ANALISIS DE LA PROPUESTA DE DESARROLLO TERRITORIAL EN LA REALIDAD DE BRASIL}

Este documento aborda las cuestiones planteadas en la realidad brasileña con la adopción de un enfoque territorial en el desarrollo de políticas públicas en el Brasil rural . Los puntos relevantes se plantearon para apoyar la discusión propuesta , como forma acrítica que se gestó e implementados en Brasil. Además, destacamos la alta concentración de la propiedad de la tierra en Brasil , como parte decisiva que bloquea muchos de los posibles efectos positivos de la propuesta, además de fuerte sesgo neoliberal de que la propuesta se ha revestido . La crítica también cae en el sesgo oficial que el concepto de territorio como un área en la que el conjunto de intereses están exentos de antagonismo, lo que anula el conflicto inherente en el proceso de desarrollo de la capital en las zonas rurales y urbanas. Por lo tanto , la adopción de la propuesta de desarrollo de la tierra no ha podido cambiar significativamente las directrices de las políticas públicas en Brasil y aún menos, ha logrado traer cambios significativos en la realidad brasileña. 


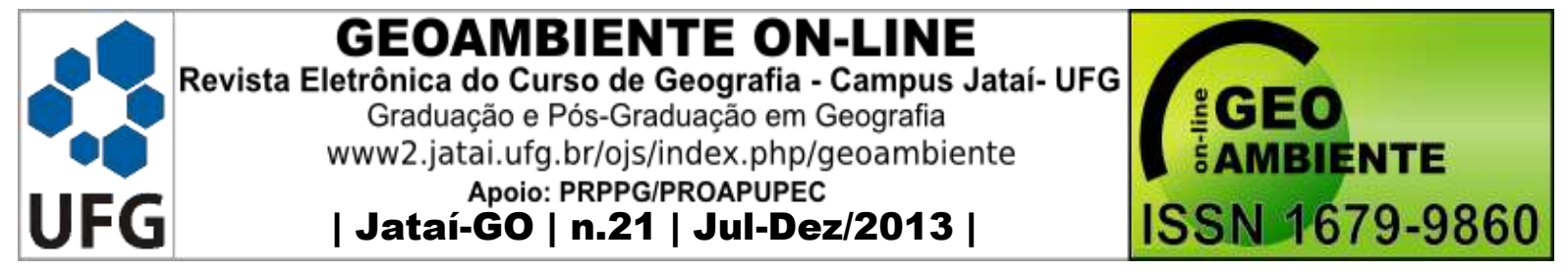

Palabras clave: desarrollo territorial, la descentralización administrativa y la participación.

\section{Introdução}

O trabalho é resultado de uma tese de doutorado em geografia, mais especificamente de um capítulo que a integra, que teve como objetivo analisar a proposta do desenvolvimento territorial na realidade brasileira. A partir dos anos 1990, o desenvolvimento territorial passou a embasar significativa parte das políticas públicas voltadas para o campo no Brasil. Em resumo, a proposta busca promover o "desenvolvimento" aproveitando o capital social (descentralização administrativa) dos territórios, o estímulo à participação (Bottom-up), a produção em "moldes sustentáveis" e o fortalecimento das atividades rurais não agrícolas, reconhecendo a multifuncionalidade do campo.

Cabe salientar, que a proposta, a priori, constitui-se num significativo avanço analítico conceitual, por proporcionar estudos e análises de maneira holística e multidimensional, engendrando a totalidade dos processos, sejam eles naturais, sociais, econômicos, políticos, culturais e ambientais. Também vem contribuir na valorização das diferenças e, também, na questão da autonomia dos sujeitos na sociedade. Além disso, procura abordar a crise ecológica integrada às questões socioeconômicas e políticas.

Deste modo, procuramos analisar e demonstrar os pontos positivos, que representam avanços, que têm sido trazidos pela proposta, bem como os problemas e bloqueios enfrentados na realidade brasileira, sendo, portanto, os limites dela frente à realidade nacional.

Apesar dos pontos positivos a ser destacados e dos aparentes avanços "prometidos", na realidade brasileira ela tem enfrentado alguns problemas para materializar seus objetivos, já que a realidade europeia é, obviamente, muito distinta da brasileira. Neste sentido, elencaremos alguns pontos que consideramos relevantes para refletir sobre os encaminhamentos da proposta no Brasil.

Para a consecução da pesquisa foi efetuado levantamento bibliográfico, aplicação de formulários a pequenos proprietários rurais na região de Jales, Noroeste do Estado de São Paulo, recorte territorial para a consecução da pesquisa. Além disso, também houve a 


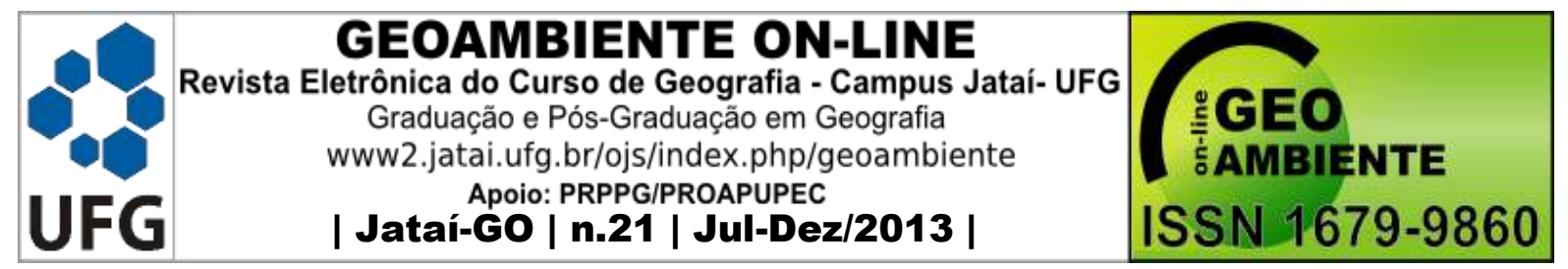

realização de entrevistas com técnicos e profissionais envolvidos na promoção de serviços e assistência técnica à agricultura regional.

\section{Avanços e limites do desenvolvimento territorial na realidade brasileira}

A partir dos anos 1990 o território passou a ganhar maior importância nas pesquisas em geografia e em várias áreas das ciências sociais. A reestruturação da economia mundial, o intenso avanço do capital (mundialização) e do neoliberalismo, a passagem do fordismo para o "capitalismo flexível", gerando desconcentração industrial e uma redefinição do papel do Estado nacional, são alguns dos fatores responsáveis por essa relevância adquirida pelo território. Com este suposto "enfraquecimento" do Estado, surgiram propostas de descentralização administrativa, incentivando a participação dos agentes privados locais, numa proposta que advoga maior eficiência na alocação de recursos, por parte dos agentes privados em detrimento do Estado.

A adoção da abordagem territorial, no desenvolvimento rural, resulta da congruência de uma série de fatores que se tornaram expressivos a partir das duas últimas décadas do século XX, como: as crescentes preocupações da sociedade com as questões ambientais - que, no caso da agricultura, tem sido expresso pelos resultados deletérios do pacote da "revolução verde", o êxito das políticas territoriais em escala européia - como o Programa Ligações Entre Ações do Desenvolvimento da Economia Rural (LEADER) e o vigoroso desenvolvimento da região centro-nordeste da Itália, mundialmente conhecida como "Terceira Itália"-, bem como a emergência de uma "nova ruralidade", com o crescimento e o aumento da importância das atividades não agrícolas no meio rural (como indústria, serviços, turismo, lazer etc..).

A proposta parte do pressuposto de que os agentes presentes no território apresentam interesses comuns e harmônicos. Basta que eles se mobilizem, para que as vantagens do território sejam aproveitadas (mercantilizadas). No entanto, nestas análises, não se faz nenhuma menção à estrutura de classes sociais, aos interesses divergentes, ao poder das elites locais, que, na maior parte das vezes, neutraliza ações para o desenvolvimento local para preservar seus privilégios.

Brandão (2007) salienta que o ressurgimento da questão do território tem se dado de maneira hegemonizada por uma visão conservadora, sendo que, somente nos anos 1970, 


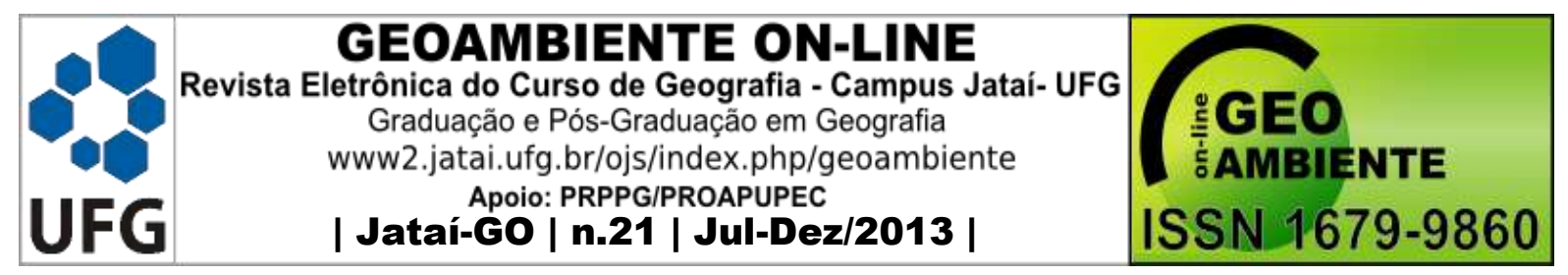

passaram a ser construídas alternativas frente ao pensamento hegemônico, que seria no caso a vertente marxista, que procura valorizar as lutas e os conflitos sociais existentes no território.

No caso específico do Brasil, não há como ignorar a intensa concentração da propriedade da terra, que impõe sérios obstáculos para alcançarmos um desenvolvimento socioeconômico mais equânime. As grandes propriedades rurais tendem a produzir monoculturas para exportação e/ou agroindústrias, como soja, cana-de-açúcar e milho de modo mecanizado, utilizando exígua mão de obra, não havendo, portanto, significativa geração de empregos. Além disso, o alto uso de agrotóxicos e o desmatamento comprometem a sustentabilidade ambiental da atividade.

Sabemos que o rural brasileiro passou e vem passando por mudanças e, que, agora, se articula de maneira distinta ao urbano, tornando-se cada vez mais complexas as relações entre tais. Agricultura em "tempo parcial” (part time), pluriatividade, multifuncionalidade, espaços periurbanos são alguns exemplos de novas denominações e conceitos que vêm surgindo para dar conta de explicar estas transformações.

Com a mundialização e o crescimento e expansão das empresas globais, observa-se uma tendência para a contínua busca de lugares mais rentáveis ao capital. Desta forma, muitos recursos naturais e amenidades que antes não despertavam atenção para a geração de renda, agora são consideradas cruciais para garantir o dinamismo de algumas áreas rurais, como a beleza das paisagens, o "ar puro", o lazer e o turismo no campo, o patrimônio cultural local e ambiental.

Os baixos preços de imóveis nas áreas rurais, para a implantação de empreendimento de turismo, lazer, condomínios, áreas residenciais, constituíram-se num forte atrativo, frente à relativa baixa rentabilidade auferida pelos produtos agrícolas tradicionais e aos altos preços imobiliários praticados nos mercados urbanos. Projetos viabilizados pela expansão da rede de estradas, que por sua vez, asseguram uma mobilidade espacial mais rápida e barata.

O rural não apresenta estas mudanças impactando as diferentes áreas de maneira homogênea, sobretudo numa realidade como a brasileira, país subdesenvolvido de grande extensão territorial e heterogêneo. O peso das atividades agrícolas é muito forte no Brasil, quando comparado com outros países, de modo que podemos citar o surgimento de centros urbanos no interior do país, como "ponto de apoio" de comércio e serviços (suporte) para as 


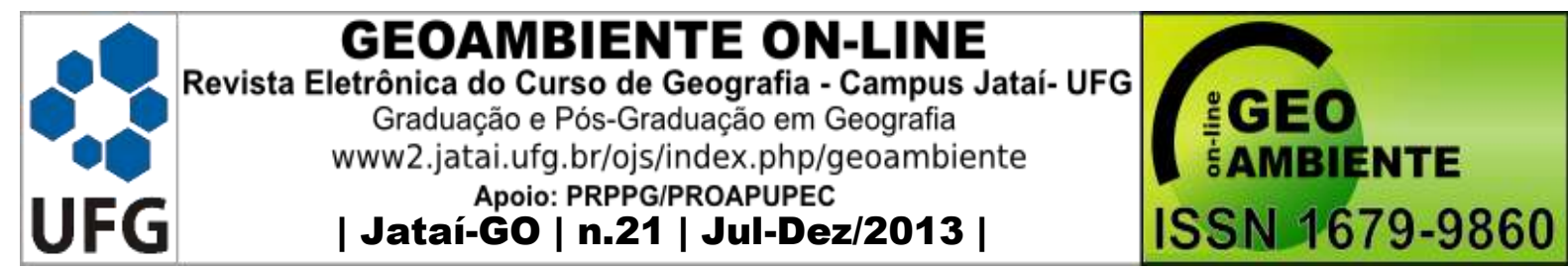

atividades agrícolas "modernas" e globalizadas (agronegócio), que ocorrem ali e que garantem a dinamicidade econômica do local, incluindo a urbana, conforme demonstra Elias (2007).

No Brasil as atividades não agrícolas, apesar da crescente relevância que adquirem, ainda são muito incipientes, ao passo que, por outro lado, a agricultura ainda conserva um papel importante no desenvolvimento rural (GUANZIROLI, 2008).

Embora seja verdade que a agricultura não é a única atividade com capacidade de dinamizar os territórios, corre-se o risco de cair no outro extremo, e acabar minimizando o papel desta atividade em função de uma amplitude de setores que muitas vezes inexiste (GUANZIROLI, 2008, p.10).

Kageyama (2008) também chama atenção para o fato de que, é importante hoje a diversificação das fontes de renda dos agricultores, porém, sem substituir a atividade agrícola, mas contribuindo para viabilizá-la.

Wanderley (2001), em estudo realizado em pequenos municípios do interior do Estado de Pernambuco, também demonstrou que a renda obtida via atividades agrícolas ainda é muito importante para o sustento de muitas famílias.

Outro fator que explica a crescente presença de atividades não agrícolas no rural é o deslocamento da indústria para áreas rurais do interior, seguindo o processo de desconcentração industrial, ocasionado pelas deseconomias de aglomeração geradas no seio dos grandes centros urbanos, como: os incômodos dos congestionamentos, os diversos tipos de poluição gerados na cidade, os altos preços dos imóveis, a maior organização sindical dos trabalhadores, a violência e criminalidade, gerando a denominada industrialização difusa.

A abordagem territorial, se aprimorada, pode vir a ser uma importante via para valorizar a pequena propriedade, contemplando a multidimensionalidade do campo, substituindo muitas destas políticas dominantes que estão aí, que focalizam apenas o econômico, como no caso do agronegócio brasileiro.

[...] a abordagem territorial é um caminho para se compreender, por exemplo, as relações de complementaridades que acontecem entre os espaços urbano e rural, seus conflitos, as redes, as relações de poder, enfim, a unidade rural-urbana no âmbito da relação E-P-C-N e das tramas territoriais. Há um processo contínuo de urbanização do espaço rural e/ou de desconcentração; formas da ligação campocidade; modernização agrícola; redes e fluxos (i) materiais; integração contratual; cooperativas; assentamentos; circulação simples de mercadorias; as migrações pendulares e definitivas [...] (SAQUET, 2007, p. 160-161, grifo do autor). 


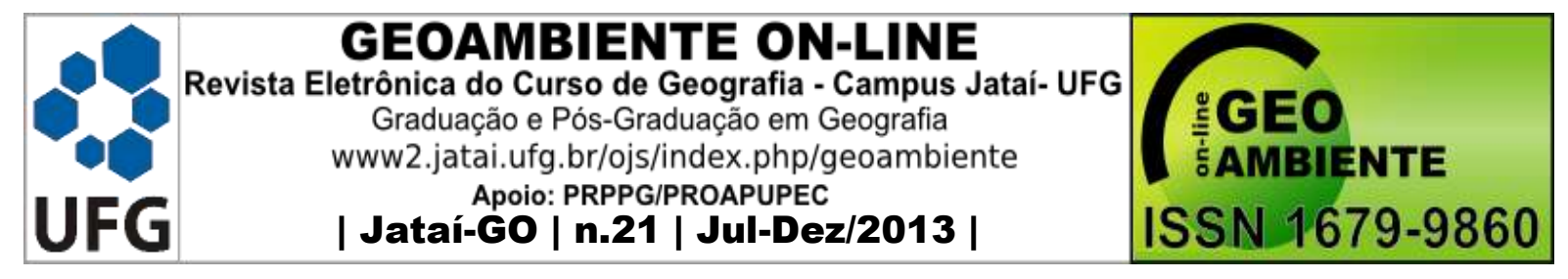

Um obstáculo para os avanços das políticas públicas de base territorial no Brasil são os interesses das velhas oligarquias agrárias regionais, que comandaram e ainda comandam o processo de produção agrícola e é detentora da maior parte das terras, conservando ainda forte poder político e influenciando o Governo na definição e na implantação das políticas, que pouco fazem para contemplar os pequenos proprietários rurais.

Ortega (2007) enfatiza que as experiências brasileiras, sob o formato de políticas territoriais, cresceram e ganharam fôlego no cenário de crise econômica e das reformas liberalizantes ocorridas durante os anos 1990. A partir daí, passaram a ocorrer tentativas de se buscar respostas autônomas para o desenvolvimento de espaços locais, num cenário em que o Estado já não promovia políticas de caráter regional, visando corrigir as distorções espaciais do desenvolvimento, como nos anos 1960 e 1970.

Sob a abordagem territorial, alguns autores buscam "transplantar" as experiências bem sucedidas da Europa à realidade brasileira. Abramovay (1999), baseando-se em estudo da Organização para a Cooperação e o Desenvolvimento Econômico (OCDE), propõe que a dinamização econômica e a geração de postos de trabalho no meio rural são resultados diretos nos últimos tempos de uma "dinâmica territorial específica", que "valoriza a identidade regional, o clima favorável ao espírito empreendedor, a existência de redes públicas e privadas ou a atração do meio ambiente cultural e natural" (p.02). Conforme já demonstrado anteriormente, esta proposta espelhou-se no modelo da "Terceira Itália" e do Programa LEADER, que, para a América Latina, criou um desenvolvimento territorial, visando amenizar a pobreza no campo, partindo da possibilidade de geração de empregos com baixo nível de investimentos.

Brandão (2007b) demonstra que, sob a proposta territorial de desenvolvimento, porém num contexto neoliberal, "Propugnam-se receitas genéricas, descurando, por exemplo, das especificidades de um contexto de país subdesenvolvido, continental, periférico e com uma formação histórica da escala local bastante peculiar”. (...) (p. 49). O grande problema desta proposta é a sua implementação na prática, pois a realidade da América Latina e do Brasil é muito diferente da realidade europeia.

Sumpsi (2007) afirma que, no caso da América Latina, a implantação de um modelo de política territorial nos moldes do LEADER ainda está muito longe de ocorrer plenamente. 


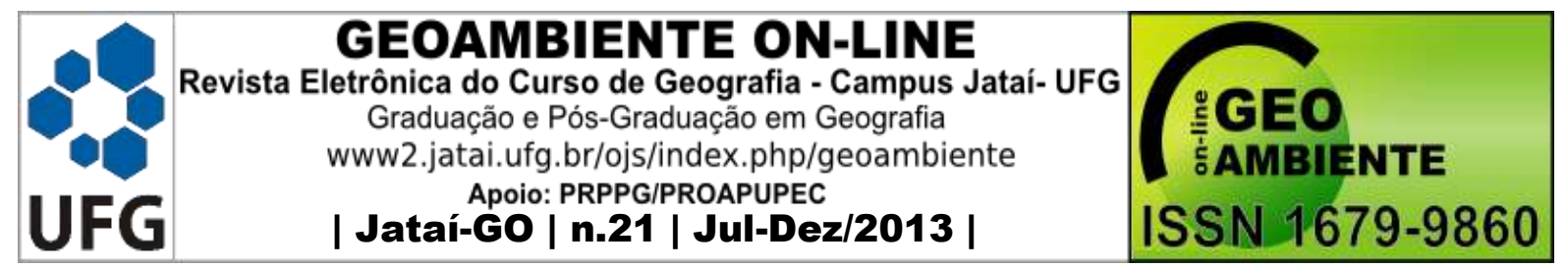

Para o autor, as políticas sob o formato territorial ainda são isoladas, desconexas e dispersas pelo território e não apresentam mínima sustentabilidade, uma vez que dependem de recursos de ONGs e/ou de agências multilaterais, como o Banco Mundial. O autor ainda demonstra, que na Europa, o programa LEADER tem sido implementado em regiões rurais que se encontram, de certo modo, "bem desenvolvidas". Lá o programa serve mais para buscar a diversificação produtiva destas áreas rurais, do que realmente para alavancar o desenvolvimento. Além disso, o LEADER tem sinergias e complementaridades de suas ações juntamente com a PAC e também pelo Programa de Desenvolvimento Regional, e que é responsável pelo investimento de grandes somas de recursos nestas áreas. Já na América Latina, os territórios rurais são bem menos desenvolvidos, o que requer investimentos de grande monta e projetos coletivos de grande escala.

Analisando o caso latino-americano, Ricupero (2001, p.51) afirma que: “(...) Faltam políticas microeconômicas, faltam políticas sociais, de renda, política de desenvolvimento das pequenas e médias empresas, de competitividade tecnológica, de comércio exterior. Falta, portanto, muita coisa.".

Assim, existe uma enorme carência em termos de políticas públicas, sobretudo, daquelas voltadas aos pequenos proprietários, que, no geral, são de baixa qualidade. As que existem são pontuais, desarticuladas, bem como, muitas vezes, falta adequação às efetivas necessidades dos pequenos proprietários, além dos problemas, que vão desde operacionalização, como falta de recursos, resistência dos proprietários rurais, dentre outros.

Outra diferença substancial, apontada por Sumpsi (2007), refere-se ao contexto socioeconômico muito distinto entre a Europa e a América Latina, em que ocorreu a transformação das áreas rurais. Na Europa, o mercado de trabalho carecia de mão de obra e, ao mesmo tempo, havia uma forte demanda por força de trabalho urbano-industrial, o que se eliminou com o êxodo rural o excedente de mão-de-obra de baixa produtividade no campo. Como resultado, ocorreu um incremento da produtividade do trabalho rural e, conseqüentemente, aumento dos níveis salariais no campo e da cidade.

Já na América Latina, existia farta oferta de mão-de-obra, em que a adoção do pacote da revolução verde, terminou por liberar força de trabalho para o setor urbano-industrial, e este, por sua vez, não foi capaz de absorver todo o contingente, gerando um enorme exército 


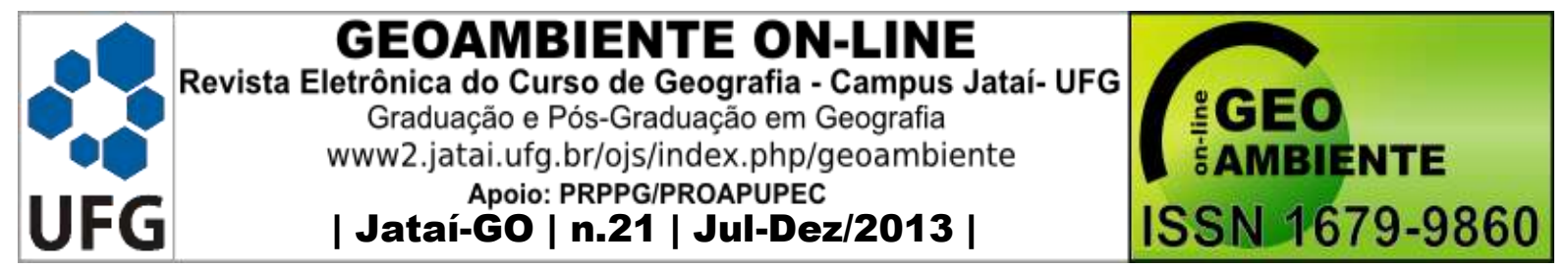

de reserva nas cidades. Isso, de certo modo, comprimiu tanto os salários urbanos, quanto os do campo.

Outro ponto importante, ressaltado por Sumpsi (2007), refere-se ao nível de organização dos produtores rurais na Europa, muito superior ao dos produtores da América Latina, sem contar a formação profissional e a qualificação da mão de obra, capacidade de empreendimento e inovação, muito superiores na Europa.

O autor ainda ressalta que a proposta territorial, na América Latina, tem apresentado grande progresso teórico, porém, o mesmo não se pode dizer na sua operacionalização. "Pero, el progreso conceptual que há producido em América Latina durante la última década em torno al desarrollo rural, no se ha visto correspondido em la misma medida por avances em el terreno operativo [...]" (SUMPSI, 2007 p. 65-66).

Apesar dos avanços trazidos, na prática existem insuficiências e limites, que se tornam verdadeiros obstáculos para se atingir o desenvolvimento e que têm sido ignorados de maneira propositada, de modo que o cerne da questão seja evitado no debate, ao se "conceder" o poder do desenvolvimento para a esfera local. Nela não há o controle sobre os instrumentos e elementos primordiais e indispensáveis (como taxas de juros, câmbio, crédito e fiscal), para se implementar uma política salutar e efetiva de desenvolvimento.

A literatura internacional adotada de maneira indiscriminada e a - crítica no país, proclama que bastaria cumprir as "exigências" da globalização, desse novo imperialismo da "partilha dos lugares eleitos", para se tornar um espaço receptivo e conquistador da confiança dos agentes econômicos mais poderosos. Assim, teríamos o fim das escalas intermediárias (e das mediações) entre o local e o global (BRANDÃO, 2007) ${ }^{1}$. O autor ainda ressalta que é preciso levar em consideração as especificidades de um país subdesenvolvido, como o Brasil, e evitar as comparações simplistas com as experiências internacionais em países com história e inserção econômica capitalista muito diferente do Brasil.

\footnotetext{
$1 \mathrm{O}$ autor ainda nos alerta que "grande parte das teorias do desenvolvimento local chegam a considerar/insinuar que estaríamos vivendo numa fase em que o poder, a propriedade etc. estivessem sendo paulatinamente diluídos nessa etapa do capitalismo, tornando-se dispersos na atmosfera sinérgica das deficiências coletivas e solidárias de um determinado local "que deu certo" (BRANDÃO, 2007, p. 50).
} 


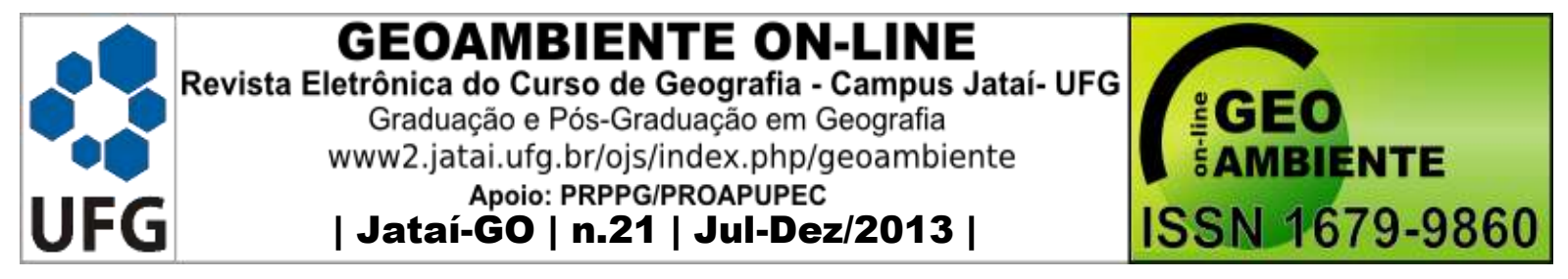

O modelo do agronegócio brasileiro, contraditoriamente à proposta territorial, contempla apenas um padrão de desenvolvimento projetado para o crescimento econômico, concentrando riqueza e renda, sem levar em conta a necessidade de distribuir renda e preservar o meio ambiente.

Compreendemos que existe espaço no Brasil para a implementação de um modelo de desenvolvimento rural, predominantemente baseado na agricultura familiar, portanto, diferente do que ocorre hoje. Haveria espaço para se pensar em soberania alimentar, geração de empregos e renda de maneira satisfatória (evitando a superexploração que ocorre nas grandes propriedades) e ainda haveria espaço para uma inserção competitiva dos excedentes agrícolas no mercado internacional.

As faces perversas deste modelo são dissimuladas, como a dilapidação e contaminação dos recursos naturais como água, solos, trabalhadores, alimentos, animais, sem contar ainda os desmatamentos e demais crimes ambientais cometidos em nome da "produção". Os gêneros agrícolas brasileiros chegam ao mercado internacional numa situação fortemente competitiva por seus baixos custos, que são conseguidos através da superexploração da força de trabalho no campo e da depredação dos recursos naturais.

Tendo em vista este quadro, infere-se que, no Brasil, o desenvolvimento rural tem sido capaz de reorientar os discursos, mas, na prática, o que se observa é que as instituições ainda estão "contaminadas" pelas antigas práticas das políticas setoriais e produtivistas. Para Favareto (2007).

A abordagem territorial, da forma que tem sido institucionalizada, não tem obtido sucesso na eliminação ou redução das desigualdades espaciais ou territoriais. Ao contrário, pelo viés neoliberal que se revestiu a proposta no Brasil, em algumas situações, pode até agravar as diferenças espaciais do desenvolvimento, em razão de que, a infraestrutura e os recursos necessários para alavancar o desenvolvimento não estão distribuídos de maneira uniforme pelo território. Como também a dinâmica capitalista, por sua própria natureza, tende a acentuar estas disparidades e não superá-las.

Neste sentido, compreendemos que, ao invés de o desenvolvimento territorial rural contribuir para dinamizar economicamente as áreas mais deprimidas e gerar emprego e renda, do jeito que ele tem sido apresentado, se corre o risco de que as disparidades regionais 


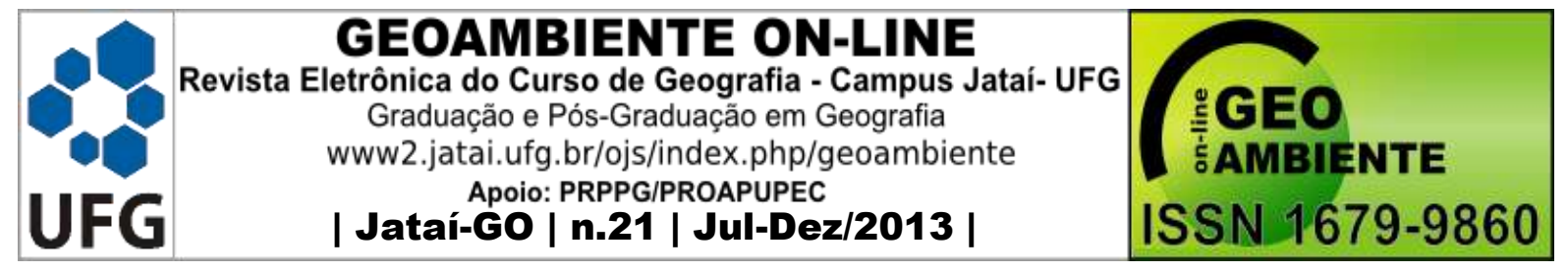

permaneçam ou até mesmo se acentuem, ao reduzirem o papel do Estado como agente planejador e indutor de políticas regionais.

Diante dessa realidade, Araújo (2007), Cano (2007) e Brandão (2007) alertam que o formato das políticas regionais no país, hoje, acaba por acentuar as desigualdades regionais, de modo que o livre jogo das forças de mercado tende a reforçar as regiões e áreas mais modernas do país em detrimento das mais atrasadas. O modelo de desenvolvimento adotado, ao contrário do que propõe, também contribui para desperdiçar as potencialidades e virtuosidades do espaço nacional, justamente por ser seletivo e excludente, "apropriado apenas para o pedaço mais moderno do Brasil” (ARAÚJO, 2007, p.19).

\section{A supervalorização da escala local: a questão da descentralização e da participação}

No final dos anos 1950, foi incorporada a necessidade de participação das populações envolvidas em políticas (projetos) de desenvolvimento. Já naquela época, ativistas e funcionários de organizações internacionais que atuavam nos países pobres, com a "pretensão" de ajudar os pobres e oprimidos, depararam-se com o fracasso dos projetos de desenvolvimento. Atribuíram este insucesso, ao fato de que não havia participação das populações envolvidas nas decisões e reformulações das ações. Passaram então a defender a inclusão de métodos de interação participativos como fundamentais para o êxito das políticas e/ou dos projetos de desenvolvimento, exigindo que se abandonassem as estratégias top-down (de cima para baixo), e passassem a adotar então políticas bottom-up (de baixo para cima) (RAHNEMA, 2000).

A adoção das políticas no formato bottom-up se deu em substituição às top-down, por conta de que, neste último modelo, predominava uma concepção linear de desenvolvimento, em que se concedia prioridade central ao econômico, sem preocupações em combater pobreza, conservar o meio ambiente e preservar as distintas culturas espalhadas pelo globo.

No Brasil, as políticas no formato bottom-up passaram a ser adotadas no contexto do processo de redemocratização do país, a partir do início dos anos 1990, buscando, portanto, resistir às determinações e decisões que vinham "de cima" (top-down), de um Governo centralizado e autoritário, e que desconsiderava as opiniões da sociedade local em relação aos projetos implementados pelo Governo (ORTEGA, 2007). A partir de então, a sociedade civil 


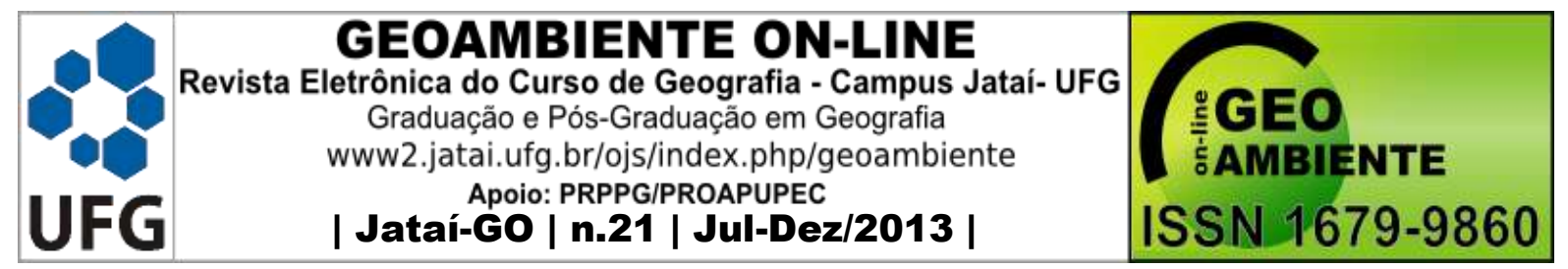

organizada passou a reivindicar cada vez maior participação nas discussões acerca dos rumos do desenvolvimento local no bojo do processo de redemocratização do país.

Arretche (sdp) lembra-nos que, naquela época, havia um grande consenso em torno da ideia de descentralização nas distintas posturas ideológico políticas, tanto de direita quanto de esquerda, supondo-se que formas descentralizadas de prestação de serviços seriam mais democráticas, contribuindo para o fortalecimento e consolidação da democracia, além da maior eficiência dos serviços públicos, possibilitando, assim, a elevação dos níveis de bemestar da população.

A promulgação da nova Constituição Federal, no ano de 1988, levou a uma descentralização administrativa dos recursos, aumentando a responsabilidade dos estados e municípios no que concerne à formulação e gestão de políticas públicas. Por conta disso, foram criados arranjos sociais locais (Conselhos) com poderes consultivos, e, às vezes, também deliberativos (ORTEGA, 2007).

As políticas públicas, antes pensadas na escala regional e articuladas com a escala nacional, deram lugar a políticas fortemente localistas, em que se procura cada vez mais delegar à sociedade o papel de se buscar o "desenvolvimento". Apesar desta proposta trazer algo de positivo, como a maior proximidade aos indivíduos locais que podem fiscalizar, sugerir e criticar tais políticas, na prática o que houve foi a desoneração do Estado do papel de conceber e implementar políticas públicas, já que a descentralização veio acompanhada de reduções e corte nas verbas públicas. De fato, não tem ocorrido, de modo geral, o comprometimento com o efetivo aprimoramento das políticas públicas a partir de estímulos a um maior envolvimento dos indivíduos-alvo das ações públicas.

A literatura do desenvolvimento local/territorial sempre buscou supervalorizar o papel das aglomerações, das proximidades, da aprendizagem e criatividade, bem como a apropriação de "sinergias coletivas" viabilizadas pela proximidade espacial, além de "constatar" muitas vezes, "uma harmonia de interesses em determinadas porções do território".

A priori, consideramos ser salutar e positiva a busca pela descentralização e participação dos agentes e indivíduos nas tomadas de decisões das políticas públicas, bem como levar em consideração as peculiaridades e as sinergias locais. Contudo, a face negativa 


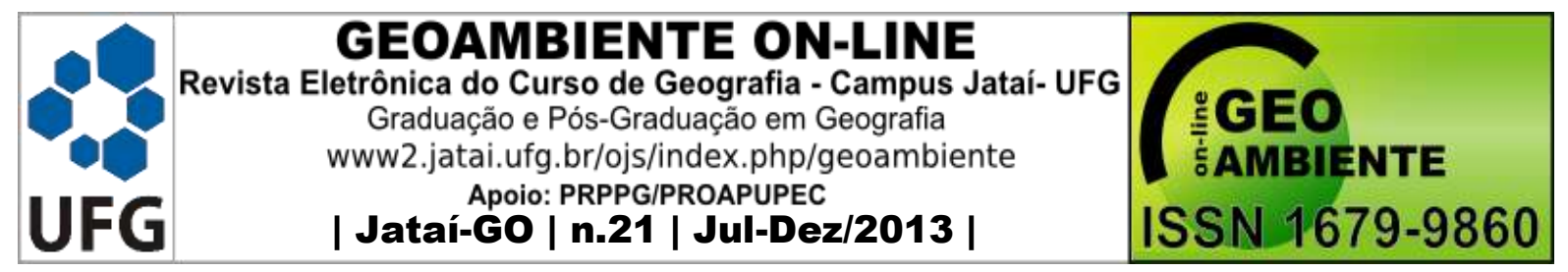

desse processo tem sido o sentido neoliberal impregnado a ela, que visa delegar à sociedade e ao "mercado", o papel que antes cabia (e cabe) ao Estado.

Vale destacar, portanto, que o advento dessas políticas no caso brasileiro, deram-se num contexto marcado por uma profunda crise fiscal do Estado, que levou a uma forte reestruturação deste e, como consequência, do formato das políticas públicas, ocasionando diminuição dos investimentos e financiamentos públicos, com privatizações e redução (redefinição) da atuação da máquina estatal ("Estado mínimo"). No caso da agricultura, foram criados os Conselhos Municipais de Desenvolvimento Rural (CMDR), como reflexo dessa descentralização administrativa, em que o município ganhou expressividade na implementação de políticas públicas.

Na esfera de ação do Estado de São Paulo, seguindo esta tendência, houve o processo de municipalização das Casas de Agricultura. Recentemente, a política estadual que vem se destacando neste sentido, buscando a participação dos agentes locais, tem sido o Programa Estadual de Microbacias Hidrográficas, implementado a partir do ano de 2000.

Em consonância com este movimento descentralizador, no plano nacional, o Governo criou o Programa Nacional de Fortalecimento da Agricultura Familiar (PRONAF), juntamente com os conselhos municipais de agricultura, direcionando crédito rural, no sentido de estimular formas coletivas de organização, como formação de cooperativas e associações de produtores rurais.

$\mathrm{Na}$ região Centro-Oeste, espaço de forte avanço do denominado agronegócio, o associativismo emergiu no âmbito do processo de incorporação capitalista do cerrado à fronteira de expansão da agricultura moderna, desencadeado a partir de meados da década de 1960 com a criação do SNCR (Sistema Nacional de Crédito Rural), que visava acelerar a expansão da utilização de máquinas, sementes e insumos químicos provenientes da indústria por meio da concessão do crédito rural farto e barato aos grandes e médios produtores rurais dedicados ao cultivo de produtos agrícolas destinados à exportação (OLIVEIRA, 2012).

O autoritarismo resultante do período ditatorial militar (1964-1984) deixou marcas ainda muito fortes. Esse perfil autoritário e conservador ainda têm forte influência na maneira como são pensadas as políticas sociais no país. Como resultado, as políticas de base centralizadas tendem a pensar o Brasil como sendo uma realidade homogênea, algo que não o 


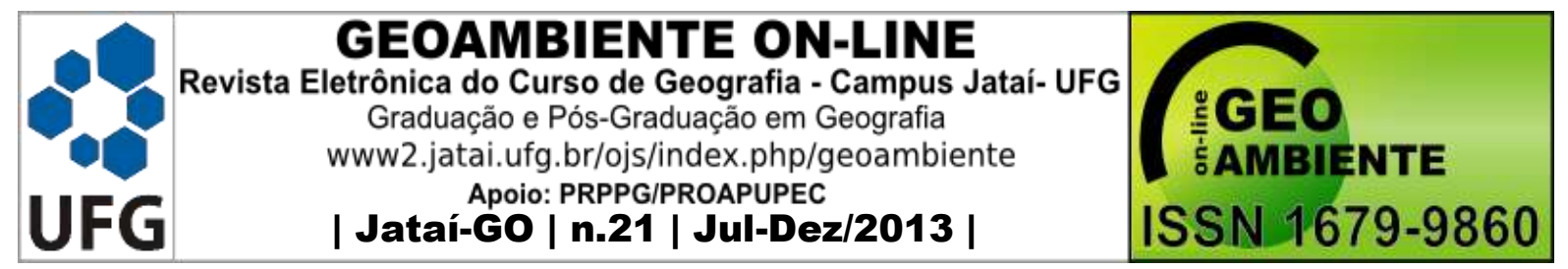

é. De fato, o país apresenta uma grande heterogeneidade que precisa ser considerada. Daí, acreditamos que a proposta territorial tende a contribuir neste sentido, de se buscar reconhecer a diversidade do país, atentando para as singularidades e particularidades dos distintos territórios.

Araújo (2007) assevera ainda que, com a hegemonia da visão neoliberal, tem disseminado cada vez mais a noção de "quanto menos Estado e quanto mais mercado, melhor; quanto mais individualidade e menos coletividade, melhor" (p.5), pois, assim, facilita a expansão e circulação do capital. Concordamos com a autora, quando ela refuta a ideia daquele Estado fechado e submetido apenas aos lobbies e, defende que deve haver um espaço amplo de discussões e disputas para a tomada de decisões em relação às políticas públicas.

Arretche (sdp) estudando a questão da descentralização no Brasil a partir do final dos anos 1980, demonstra que, contrariamente às correntes que defendem uma redução da atuação do Estado na economia, ela considera o papel do Estado como estratégico, para que o processo de descentralização tenha êxito, necessitando que haja uma redefinição do papel deste sob um novo pacto federativo em que se deu a descentralização administrativa (ARRETCHE, SDP).

A autora supracitada ainda atenta para o fato de que, no Brasil, o processo de descentralização das políticas sociais tem sido caracterizado por desigualdades na formulação e no ritmo de implementação das políticas setoriais e na qualidade dos serviços prestados. Essa dificuldade não pode ser resolvida por iniciativas locais, por conta da forte heterogeneidade regional, mas depende da intervenção do Governo Federal, para que não se acentuem as disparidades regionais.

As estratégias de desenvolvimento bottom-up, a princípio gerariam maior organização e envolvimento da comunidade local, maior preocupação com os aspectos sociais da localidade; maior conhecimento das necessidades das famílias e das características locais, podendo-se aumentar a eficiência na exploração de suas potencialidades; maior comprometimento da comunidade com o êxito dos programas implementados. Porém, Brandão (2007b) alerta para o fato de que as políticas voltadas para o desenvolvimento que apresentaram os melhores resultados foram justamente aquelas que buscaram integrar as variadas escalas e não aquelas que apresentam forte viés localista. Importante esclarecer que a 


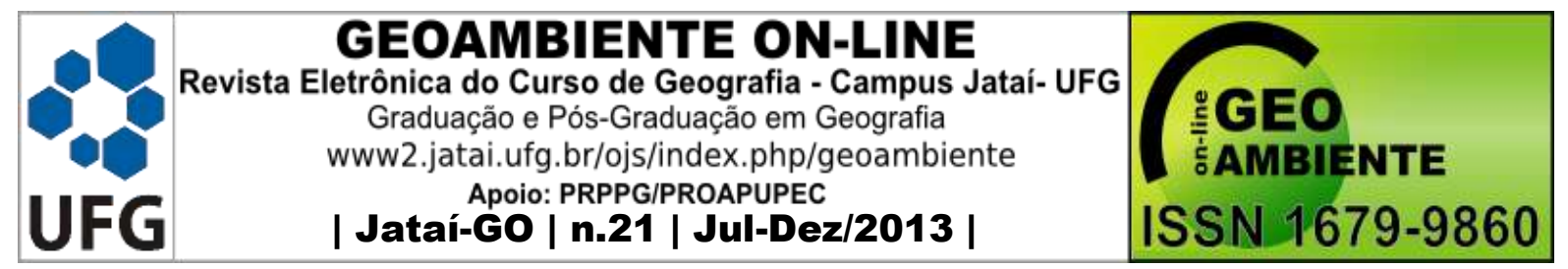

escala ajuda, pois os diferentes problemas a serem enfrentados, requerem recortes escalares específicos e adequados para a ação de políticas públicas, que, muitas vezes, necessitam da articulação dos distintos níveis das esferas do poder para enfrentá-los.

Como parte dessa estratégia de se supervalorizar a escala local no processo de desenvolvimento, a intensificação do processo de mundialização (globalização) da economia, nos anos 1990, e a forte desregulamentação dos mercados criaram um ambiente fortemente competitivo e instável, em que, no plano local, se deveriam formular estratégias para garantir uma sólida inserção do local na economia nacional e global. Forjou-se, portanto, uma máxima que assim exprimia: "pensar globalmente, agir localmente". Isso veio reforçar que as escalas, que valem para se pensar estrategicamente o desenvolvimento, são apenas as locais e a global. No entanto, de acordo com Brandão (2007), sabe-se que o capital articula e maneja a divisão social do trabalho em todas as escalas, de acordo com as necessidades de acumulação.

As agências multilaterais como o FMI e o Banco Mundial, por exemplo, passaram a implantar e direcionar políticas de desenvolvimento e combate à pobreza, focando a escala local a partir dos anos 1990. Isto encerra um forte contrasenso, à medida que a pobreza é de fato gerada pelas anomalias do modelo estrutural econômico nacional e global, ficando com o local a responsabilidade de amenizá-las, em acordo com a prerrogativa de se reduzir o papel do Estado. Isso se torna um contrasenso maior ainda quando se pensa que o Banco Mundial, por exemplo, "que exerce um amplo domínio sobre a política de desenvolvimento com que se implementa a escala global, tem o poder de reescalar os âmbitos espaciais em que opera e, dessa forma, manter ou fortalecer seu poder" (MONTENEGRO GÓMEZ, 2006, p.237). Ou seja, pelo amplo poder que esta instituição possui em escala global, ela poderia intervir, obviamente, nos modelos econômicos globais e nacionais e reverter a geração de pobreza. No entanto, elas realizam políticas compensatórias em âmbito local, que não têm a mesma eficácia.

Significativa parte dos municípios do interior do país depende muito de recursos repassados pelo Fundo de Participação dos Municípios (FPM). De forma que as políticas projetadas e implementadas nestes municípios não se sustentam localmente, necessitam de um aporte externo de recursos, tanto da esfera estadual quanto da federal. No entanto, a tendência 


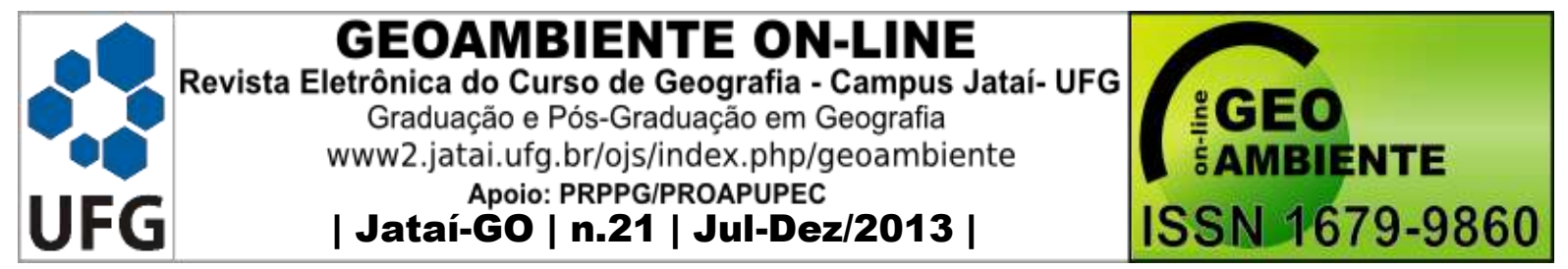

dominante parece se dar de modo contrário, sob as políticas territoriais, o que se mostra negativo.

Ortega (2007) enfatiza que é necessária a articulação entre políticas territoriais/locais articuladas com outras esferas de poder. Deste modo, o referido autor defende uma combinação das atuações/políticas de caráter local (bottom-up) e central (top-down), para que os benefícios sejam potencializados, sem perder de vista o papel fundamental a ser desempenhado pelo Estado.

Os Conselhos Municipais de Desenvolvimento Rural, criados a partir da Constituição de 1988, constituem um fórum de discussão e de formulação de políticas rurais, cabendo aos conselheiros a elaboração e a coordenação de Planos municipais, com a participação efetiva dos integrantes da comunidade envolvida. No entanto, Sumpsi (2007) enfatiza que as elites locais têm se apropriado dos recursos e utilizam-nos em seu proveito político próprio, reproduzindo, no local, os mesmos esquemas clientelistas e autoritários. Isso tem retirado dos Conselhos Municipais o principal caráter pelo qual ele foi criado, que era de ser instrumento de participação, fiscalização e controle por uma sociedade autônoma em relação ao Poder Público.

Abramovay (2001) aponta que os Conselhos foram criados e estimulados a proliferarem pelo país, como condição para que o município tivesse acesso aos recursos públicos, como do PRONAF, não expressando, assim, a dinâmica social local própria de participação e legítimo envolvimento.

Outro problema relativo à descentralização tem sido a inércia da maior parte dos municípios, que, apesar de todos os esforços, ainda adota uma postura passiva em relação ao desenvolvimento e às políticas públicas. "No entanto, os municípios não têm atuado efetivamente na elaboração de tais programas e sequer têm fornecido a assistência técnica básica aos produtores rurais" (HESPANHOL; HESPANHOL, 2004, p. 7).

Analisando os Conselhos de Desenvolvimento Rural na região de Presidente Prudente, no Oeste Paulista, Hespanhol; Hespanhol (2004, p.14) constataram que a maior parte deles não atingiu um nível satisfatório de funcionamento “[...] em razão de problemas derivados da falta de articulação dos agentes locais, da deficiente participação dos membros dos conselhos, 


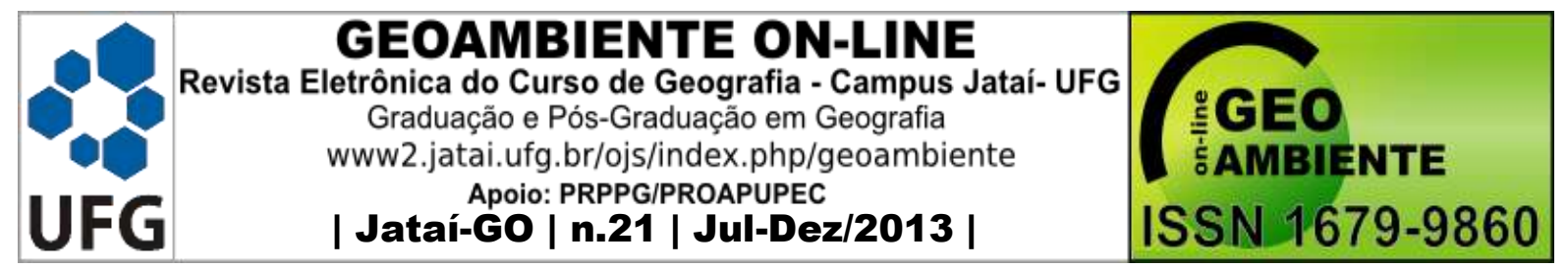

da ingerência de interesses políticos partidários, da falta de projetos efetivos e de recursos para implementá-los, entre muitos outros.”.

Oliveira (2004), em sua análise sobre os Conselhos Municipais de Desenvolvimento Rural no Estado de São Paulo, aponta que estes, pela forma com que vêm sendo operacionalizados, não se constituem como um instrumento para o desenvolvimento local, justamente por falharem na promoção legítima de participação e concertação social. Esta falha se deve ao fato de que, a implementação dos CMDRs se deu de maneira a reproduzir os esquemas de dominação política em âmbito local, como os clientelismos e o forte poder conservador das oligarquias locais.

Apesar de alguns avanços, as políticas públicas ainda continuam operando num modelo top-down, porém, disfarçadas de bottom-up, pois elas " [...] limitam de antemão a oferta de alternativas de investimento a serem feitos pelos governos a um número limitado de alternativas. Não haveria, portanto, real participação." (GUANZIROLI, 2008, p. 7).

A descentralização e o estímulo à participação dos envolvidos nas políticas de desenvolvimento são fundamentais, por conta de que o Estado centralizado não consegue gerir a multiplicidade e a diversidade de ações, que exigem flexibilidade e conhecimento das especificidades, peculiaridades e demandas locais num país continental como o nosso. Outro problema é a exígua experiência participativa dos proprietários rurais em tomar decisões e se mobilizarem, num contexto marcado pelo autoritarismo.

Os usos clientelistas e fisiológicos dos recursos públicos, que sempre estiveram presentes no aparelho estatal brasileiro, diferentemente do que argumentavam as teses descentralizadoras de que na escala local estas práticas seriam inibidas, Arretche (SDP) reitera que tais práticas independem da escala de políticas ou ações e, sim, das instituições encarregadas.

Ortega (2007), assim como Brandão (2007), admite que a proposta do desenvolvimento territorial, do modo como está colocada, é insuficiente para garantir efetivamente o desenvolvimento, por:

- desconsideração do ambiente macroeconômico;

- minimização dos conflitos políticos locais;

- minimização da estrutura das classes sociais; 


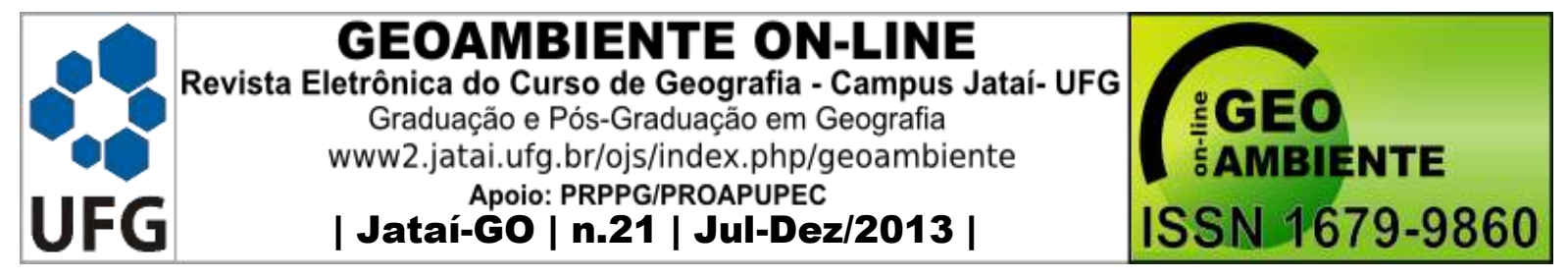

- minimização do papel do espaço e das políticas nacionais;

- necessidade de levar em consideração a história e inserção local na ordem capitalista.

Existe um viés ideológico embutido nesta supervalorização do local, para atrair investimentos e beneficiar o grande capital, no caso as grandes empresas. Com isso, ofusca-se e desvia o debate das questões estruturais, que deveriam ser efetivamente motivo de preocupação da sociedade, de modo que os enormes limites estruturais colocados à regulação local são subestimados, como "a política, os conflitos, as classes sociais, o papel da ação estatal, a nação e o espaço nacional. [...]” (BRANDÃO, 2007, p. 36-37). Também o local não domina os fatores de ordem macroeconômica como taxas de juros, relação salarial, câmbio, políticas monetárias e financeiras etc., o que o impede realmente de estabelecer políticas efetivas de desenvolvimento.

Compreendemos que, para o efetivo desenvolvimento de uma área/região é necessária a mobilização dos agentes sociais locais. Porém, há que se destacar que isso deve ocorrer juntamente com ações e políticas emanadas e coordenadas pelo Estado forte e atuante na correção das distorções e desigualdades. Aliás, deve-se ressaltar que essa "coordenação" dos atores ou agentes locais, em prol do desenvolvimento, não se dá de maneira serena e harmônica. Numa sociedade capitalista, mesmo no plano local, os objetivos dos indivíduos que pertencem às classes sociais distintas, têm ações distintas e muitas vezes opostas, gerando conflitos e tensões, já que existem fortes assimetrias na apropriação do poder, recursos e capital por parte dos indivíduos. O autor reitera ainda que, com a globalização, o capitalismo adquiriu um poder muito grande em manejar as diferentes escalas, sempre alterando a divisão social do trabalho em seu benefício, de modo a aproveitar as vantagens ofertadas pelos distintos lugares. Daí que as ações de cunho local são relevantes, porém, se apresentam insuficientes para se gerar o desenvolvimento efetivo, havendo a necessidade de integrar ações e políticas nas mais variadas escalas e articuladas entre si. Os autores considerados "localistas":

Parecem não atentar para o fato de que o sistema capitalista recorrentemente aprofunda e complexifica a divisão social do trabalho, em todas as suas dimensões, inclusive na espacial. Ele aperfeiçoa compulsivamente sua capacidade de manejar as escalas espaciais em seu benefício. É por isso que nenhuma escala per se é melhor ou pior. Na verdade, elas ganham nova significação em cada momento histórico particular (BRANDÃO, 2007, p. 30). 


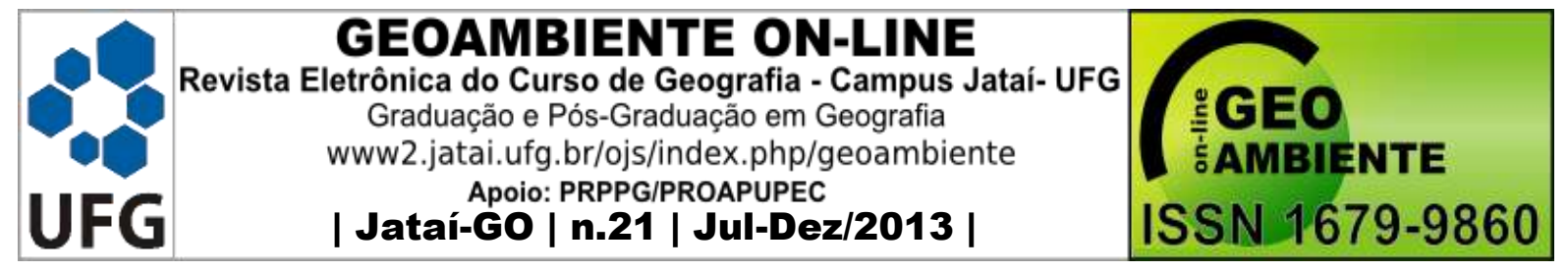

Com a descentralização administrativa, o que se viu foi que as elites locais, muitas vezes, antigas oligarquias que se perpetuam no poder, passaram a utilizar os recursos e o poder em prol de si mesmas, gerando, assim, exíguos ou nenhum avanço na melhoria das condições de vida das populações locais. O poder dominante local conseguiu solapar muito dos possíveis avanços positivos que a descentralização poderia ter trazido. A respeito da participação sob o desenvolvimento rural, Montenegro Gómez destaca que este gerou

[...] uma participação reificada, construída sem pluralidade, fortemente controlada pelos grupos dominantes, sem poder de decisão, apenas de consulta, ou decidindo sobre questões menores que não provocam mudanças fundamentais; [...] (MONTENEGRO GÓMEZ, 2006, p.216- 217).

Portanto, na perspectiva de Montenegro Gómez (2006), as fortes diferenças entre o discurso, que promete grandes melhorias, e o que se vê na prática, em que há exíguas ou nenhuma melhoria efetiva em relação aos Conselhos Municipais de Desenvolvimento Rurais, se deve ao fato de estes conselhos terem sido criados como mais um instrumento de controle a serviço do Estado e do capital, de modo que, para controlar, é preciso que se ouça a população envolvida.

A participação trazida nos moldes das políticas públicas do desenvolvimento territorial rural carece de aprimoramentos e ajustes, pois, seria ingênuo pensar que as classes dominantes disponibilizariam poder e recursos de caráter estratégico, de forma democrática e ampla no plano local, acessível a todas as classes sociais. Oferece apenas uma participação limitada, debatendo questões sem grande relevância.

No entanto, apesar destas limitações já elencadas, a participação, mesmo nestes moldes, representa um avanço, ainda que pequeno. A partir daí, cabe aos pequenos proprietários e trabalhadores rurais, mobilizarem-se em busca de maior participação e exercer parte do poder no direcionamento das políticas públicas da qual participam.

Numa contundente crítica à abordagem territorial do desenvolvimento, Favareto (2007) salienta que a abordagem territorial veio apenas a ser somada, adicionada, e, portanto, "[...] sem a devida mudança institucional capaz de conferir um horizonte estratégico às ações e um caráter efetivamente intermunicipal e intersetorial, [...]” (2007, p. 01). Depreendemos daí que a abordagem territorial tem sido muito eficaz na mudança dos discursos e nas discussões teóricas, apresentando efetivamente exíguos resultados na mudança da realidade. 


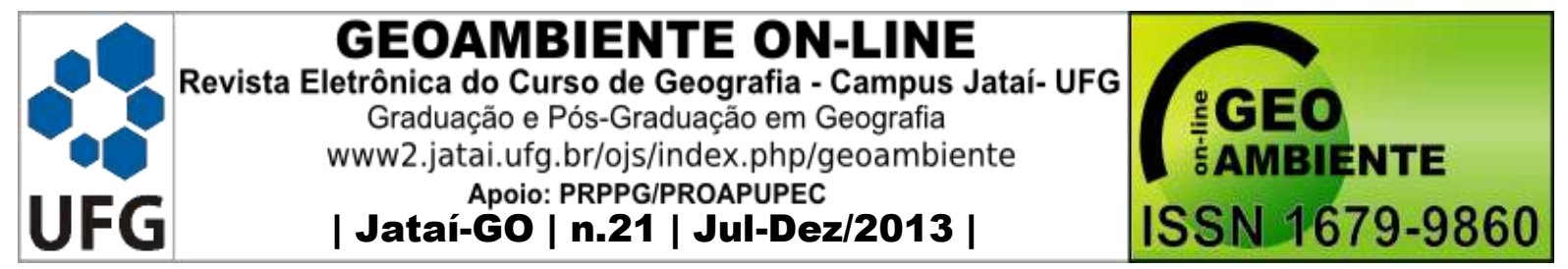

As mudanças, no sentido do desenvolvimento contemporâneo, devem começar a se efetivar concretamente, à medida que a abordagem territorial do desenvolvimento for realmente aprimorada e contemplada em suas múltiplas dimensões ou esferas, possibilitando deslocar gradativamente o econômico do centro das questões cruciais e conceder maior relevância ao político, ao social, ao cultural e ao ambiental.

Apesar do avanço teórico representado pela abordagem territorial, mesmo sabendo existir, ainda que teoricamente, abordagens que acabam sendo setoriais, na prática, ela precisam de muitos ajustes e mudanças. Para que ela venha a contribuir efetivamente para a promoção do desenvolvimento, é preciso que se reconheçam as contradições sociais, políticas, econômicas, os interesses envolvidos (elementos imateriais), que terão reflexos na construção e conformação do território material.

De maneira sintética, podemos afirmar que, com a adoção do desenvolvimento territorial rural, foi possível encontrar "pistas", "saídas" para tentar equacionar, em âmbito das ciências humanas, algumas questões de ordem teórico-metodológicas, no que se refere às recentes mudanças que acometem o rural, à medida que vêm se tornando mais complexas as relações deste com as cidades, ao mesmo tempo em que este não se restringe apenas ao locus das atividades agrícolas. Além disso, o desenvolvimento territorial rural trouxe mudanças no que concerne ao novo formato das políticas públicas, priorizando a descentralização e a participação dos agentes locais, encarando a realidade como heterogênea e multifacetada e atentando para a questão ambiental.

Porém, em sua operacionalização, a proposta vem apresentando problemas e limites que precisam ser superados, para que ela tenha êxito em seus projetos, sobretudo num país subdesenvolvido como o Brasil. Para que isso ocorra, alguns pontos da proposta precisam ser discutidos, aperfeiçoados e reformulados, como: o excessivo localismo das políticas, a participação "controlada" dos agentes locais, o caráter neoliberal no planejamento das políticas públicas.

Por outro lado, para os estudiosos ligados à corrente pós-estruturalista ou pósdesenvolvimentista, o desenvolvimento territorial que emergiu a partir do final dos anos 1990, não tem nada de inovador e apenas representa um "discurso renovado" para continuar como um instrumento ideológico a serviço da dominação e do controle social. 


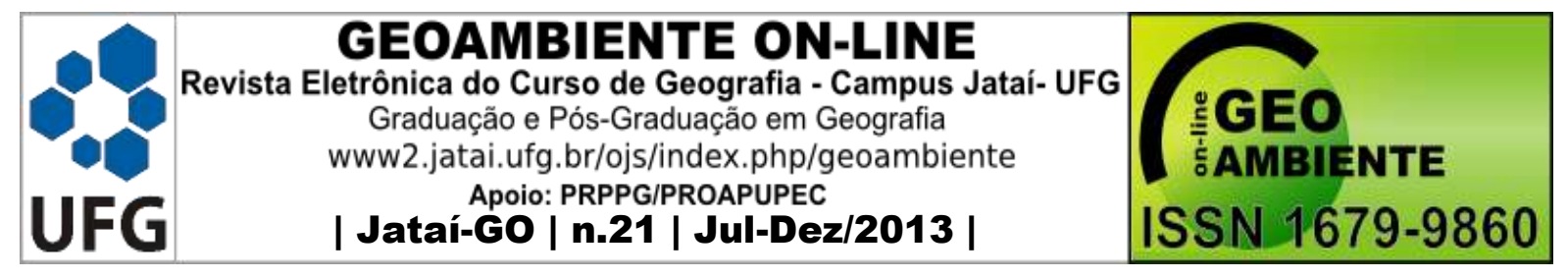

Apesar de reconhecermos que há uma distância significativa entre o que tem sido proposto em nível acadêmico-teórico e das políticas públicas e o que realmente tem se materializado na prática, compreendemos que o padrão do desenvolvimento territorial rural trouxe contribuições e inovações que necessitam serem aprimoradas, a partir de uma mobilização e organização dos agentes sociais que a integram e cobrar estas melhorias do Poder Público, sendo que este também não deve se omitir em relação à implementação de políticas públicas efetivamente eficazes na resolução dos problemas sociais, econômicos e ambientais.

Entendemos ser este o caminho para edificar uma sociedade menos perversa e construirmos um modelo de desenvolvimento rural mais equânime, do ponto de vista social, garantindo renda aos proprietários rurais, ao mesmo tempo que se paute por ações que tenham reduzido impacto/destruição da natureza.

O desenvolvimento territorial rural apresenta sua face "inovadora", com alguns avanços que devem ser reconhecidos, porém também apresenta limites e precisa ser aprimorado, para que apresente efetivamente melhorias no padrão de vida da população rural, com redistribuição de renda e atenuação da concentração da terra, adoção de manejos e tecnologias menos predatórias dos recursos naturais, buscando e caminhando em direção à sustentabilidade.

\section{Considerações finais}

É preciso salientar, que diante da realidade brasileira, a proposta territorial, apesar de inovadora, por si só não irá ser capaz de desencadear processos de melhorias e desenvolvimento efetivo. Numa sociedade de classes, por mais inovadora que seja a abordagem territorial, ela não é capaz de, por si só, trazer os benefícios a todas as parcelas da população. É necessário, cada vez mais, portanto, maior envolvimento e participação efetiva das classes subalternas para aprimorar e estabelecer ações que venham a contemplar seus anseios, base inicial para construirmos uma sociedade menos desigual.

A proposta do desenvolvimento territorial tem ficado restrita apenas aos discursos, pois, na prática, enfrenta muitos problemas. De imediato, verificou-se que um dos problemas 


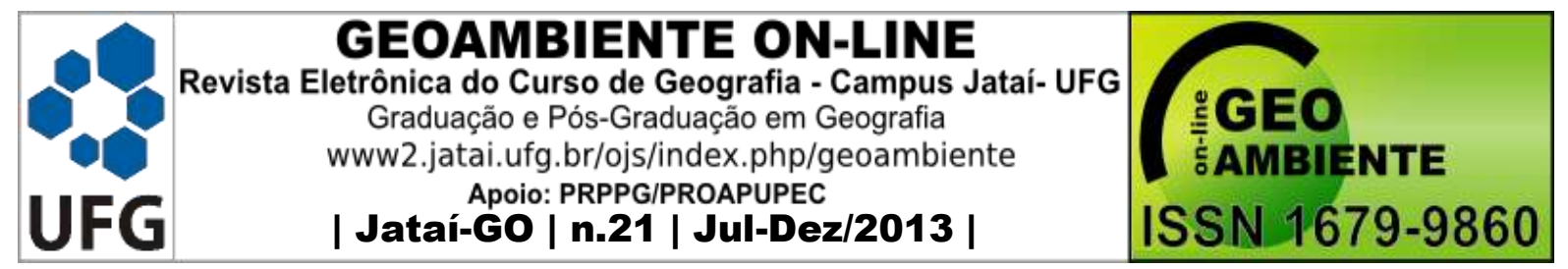

relativos a este tipo de política, no Brasil, refere-se às distintas realidades apresentadas entre a Europa e o Brasil. A proposta foi incorporada de modo acrítico no Brasil, já que as características bastante peculiares da região Centro-Norte da Itália, são de difícil "reprodutibilidade" em outros lugares. Portanto, difícil acreditar que será "recriado" o mesmo cenário italiano em algumas regiões do Brasil.

O conceito de território tem sido utilizado de maneira acrítica, desvinculando-o das questões relativas ao poder. Numa sociedade de classes como é a capitalista, mesmo no plano local/regional, ocorrem divergências de interesses entre as diferentes classes, bem como maior poder por parte de uma classe sobre a outra, ou seja, o poder está desigualmente distribuído, o que inviabiliza muitas vezes uma participação legítima e que discuta as questões primordiais do desenvolvimento de maneira efetiva.

Com o enfraquecimento do Estado em implementar políticas de desenvolvimento regional, defende-se atualmente a mobilização local para alavancar o desenvolvimento. Porém, neste momento de mundialização da economia, com o forte aprimoramento dos meios de transporte e de comunicações e o fortalecimento das grandes corporações (firmas) mundiais, o capital cada vez mais consegue manejar ações nas diferentes escalas (local, regional, nacional e global) para fazer valer seus interesses. Apenas "pensar globalmente e agir localmente" não contempla uma efetiva estratégia de desenvolvimento territorial, que deve envolver todas as escalas. No caso, pensar o desenvolvimento apenas "globalmente e localmente" não terá o mesmo êxito se tal estratégia envolver todas as escalas, já que, as políticas de juros, crédito, câmbio entre outras, dependem das decisões situadas no Governo Federal, ou seja, na escala nacional.

Os avanços que seriam obtidos a partir da descentralização e da participação foram neutralizados com o caráter neoliberal, em que se defendem cortes nos orçamentos públicos e redução do papel do Estado no provimento de serviços públicos básicos. A descentralização delegou responsabilidades aos Estados e municípios, ao passo que não repassou os recursos na mesma proporção das novas incumbências. Além disso, os municípios brasileiros, tradicionalmente, não apresentam condições e recursos para a elaboração e implementação de políticas públicas. Além disso, existe o autoritarismo, o uso eleitoreiro e clientelístico dos 


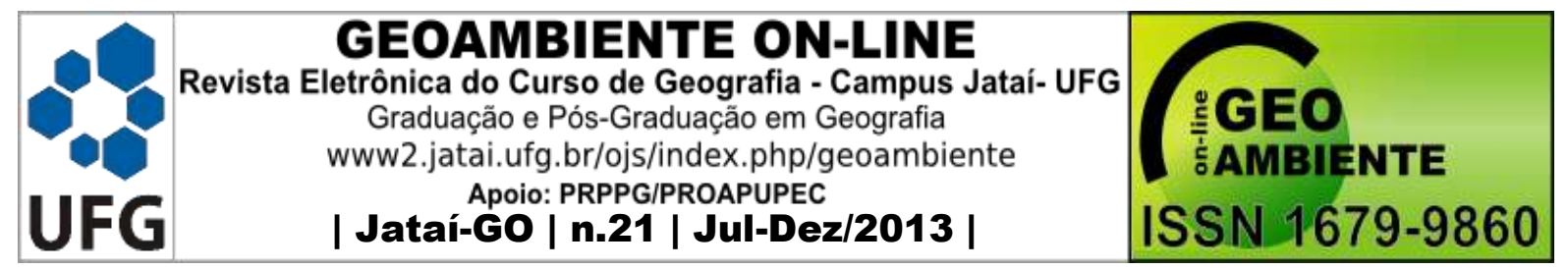

recursos pela classe dominante local, contribuindo para neutralizar muito dos seus efeitos positivos que poderiam ter emergido com a adoção da proposta territorial.

No mesmo sentido, os estímulos à participação dos agentes locais têm sido inegavelmente um avanço. No entanto, essa participação apresenta problemas e tem sido limitada, já que os proprietários rurais apenas decidem sobre assuntos e/temas que não dão margem a significativas mudanças. Do outro lado, existe também resistência e falta de tradição dos proprietários rurais em participar de organizações coletivas, como associações ou cooperativas.

Um fator de ordem estrutural e que bloqueia a expansão de um efetivo desenvolvimento rural reside na intensa concentração da propriedade da terra no Brasil. A resolução desta questão passa pela realização de ampla reforma agrária no país, visando alcançar a sustentabilidade em todas as suas dimensões, seja socioeconômica, a partir de maior distribuição de renda, seja ambientalmente, buscando compatibilizar cultivos vegetais e criação animal em pequenas propriedades.

No mesmo sentido, os estímulos à participação dos agentes locais têm sido inegavelmente um avanço. No entanto, essa participação apresenta problemas e tem sido limitada, já que os proprietários rurais apenas decidem sobre assuntos e/temas que não dão margem a significativas mudanças. Do outro lado, existe também resistência e falta de tradição dos proprietários rurais em participar de organizações coletivas, como associações ou cooperativas.

\section{Referências}

ABRAMOVAY, Ricardo. Agricultura familiar e desenvolvimento territorial. Reforma Agrária - Revista da Associação Brasileira de Reforma Agrária-vols. 28 nº 1,2, 3 e 29, nº1 - Jan/dez 1998 e jan/ago 1999.

ARAÚJO, T. B. Apresentação. In: BRANDÃO, Carlos Antônio. Território $e$ desenvolvimento: as múltiplas escalas entre o local e o global. Campinas, Editora da UNICAMP, 2007. 


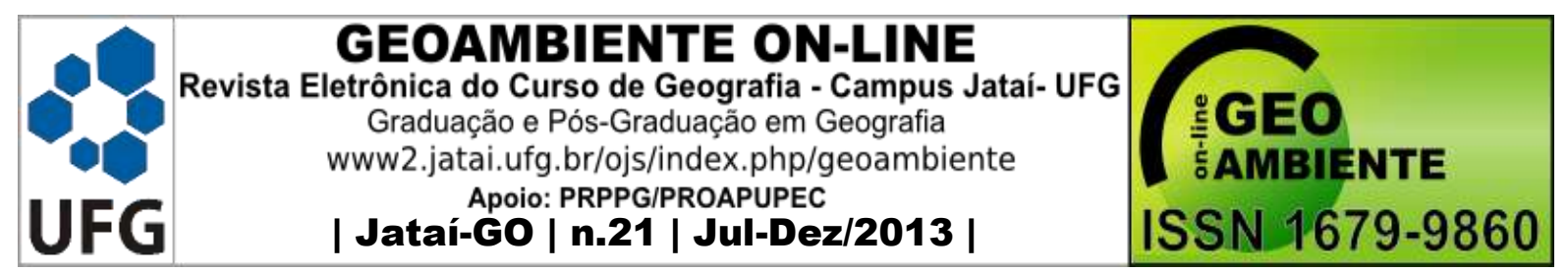

OLIVEIRA, A, R. de. Associativismo e desenvolvimento rural em Goiás: uma análise das estratégias de organização do agronegócio e da produção familiar. In: Anais do XXI Encontro Nacional de Geografia Agrária - ENGA; UFU, Uberlândia-MG, 2012.

ORTEGA, Antonio César; Almeida Filho, Niemeyer (Org.). Desenvolvimento territorial, segurança alimentar e economia solidária. Campinas: Editora Alínea, 2007.

RAHNEMA, Majid. Participação. In: SACHS, Wolfgang Sachs (editor). Dicionário do desenvolvimento: guia para o conhecimento como poder. Tradução: Vera Lúcia M. Joscelyne, Susana de Gyalokay e Jaime A. Clasen. Petrópolis, RJ: Vozes, 2000.

RICÚPERO, Rubens. A busca de sentido para a economia e o desenvolvimento. In: ARBIX, Glauco; ZILBOVICIUS, Mauro; ABRAMOVAY, Ricardo. Razões e ficções do desenvolvimento. São Paulo: Editora da UNESP; EDUSP, 2001.

SAQUET, Marcos Aurélio. Abordagens e concepções de território. São Paulo: Expressão Popular, 2007.

SUMPSI, José Maria. Desarrollo rural com enfoque territorial: diferencias y semejanzas de lãs experiências de la Unión Europea y América Latina. In: Ortega, Antonio César; Almeida Filho, Niemeyer (Org.). Desenvolvimento territorial, segurança alimentar e economia solidária. Campinas: Editora Alínea, 2007.

VAN DER PLOEG et al. Rural development: from practices and policies towards theory. In: Sociologia Ruralis, vol 40, n 4,, Oxford, 2000.

WANDERLEY, Maria de Nazareth Baudel. A ruralidade no Brasil moderno. Por un pacto social pelo desenvolvimento rural. In: ¿Una nueva ruralidad en América Latina?. Norma Giarracca. CLACSO, Consejo Latinoamericano de Ciencias Sociales, Ciudad Autónoma de Buenos Aires, Argentina. 2001. 